\title{
KARAKTERISTIK PENGERINGAN JAHE MERAH (Zingiber officinale var rubrum rhizome) DENGAN METODE PENJEMURAN DAN MENGGUNAKAN ALAT PENGERING TIPE HOHENHEIM
}

\author{
(Drying Characteristics of Red Ginger Under Sun Drying and By Using Hohenheim Type Dryer)
}

\author{
Bunga Mentari ${ }^{1}$, Diswandi Nurba ${ }^{1}$, Rita Khathir ${ }^{1 *}$ \\ ${ }^{1}$ Program Studi Teknik Pertanian, Fakultas Pertanian, Universitas Syiah Kuala
}

\begin{abstract}
Abstrak. Penelitian ini bertujuan untuk mengkaji karakteristik pengeringan jahe merah dengan metode penjemuran langsung dan menggunakan alat pengering tipe Hohenheim. Penelitian ini menggunakan Rancangan Acak Kelompok (RAK) non faktorial dengan 2 taraf, yaitu penjemuran langsung (B1) dan menggunakan alat pengering tipe Hohenheim (B2). Hasil penelitian menunjukkan bahwa rata-rata suhu pengeringan pada alat pengering tipe Hohenheim lebih tinggi dibandingkan rata-rata suhu pengeringan secara penjemuran, sedangkan kelembaban relatif dalam alat pengering tipe Hohenheim lebih rendah dibandingkan kelembaban relatif pada sistem penjemuran. Susut bobot dan laju pengeringan pada pengeringan menggunakan alat pengering tipe Hohenheim lebih tinggi dibandingkan dengan metode penjemuran. Kadar air pada pengeringan menggunakan alat pengering $(19,84 \%)$ secara nyata lebih rendah dibandingkan pada metode penjemuran $(37,02 \%)$. Metode pengeringan tidak berpengaruh terhadap kontaminasi benda asing, namun pengeringan menggunakan alat pengering tipe Hohenheim menghasilkan warna jahe merah yang lebih cerah dibandingkan dengan metode penjemuran. Oleh karena itu dapat disimpulkan bahwa pengeringan menggunakan alat pengering tipe Hohenheim lebih baik dibandingkan metode penjemuran.
\end{abstract}

Kata kunci : jahe merah, pengeringan, alat pengering tipe Hohenheim.

Abstract. This study aimed to assess the drying characteristics of red ginger under sun drying method and by using Hohenheim type dryer. This study used a non factorial randomized block design with drying method at 2 levels, namely the sun drying method (B1) and Hohenheim type dryer (B2). The results showed that the average temperature drying in Hohenheim type dryer is higher than the average temperature of sun drying method, while the relative humidity in the dryer is lower than the relative humidity of sun drying method. The weight loss and the drying rate of red ginger dried by using Hohenheim type dryer is higher than that of sun drying method. The moisture content of red ginger dried by using Hohenheim type drier (19.84\%) was significantly lower than that of sun drying method (37.02\%). Drying method did not affect the rate of contamination on both methods. However, red ginger dried by using Hohenheim type drier has brighter colour than that of sun drying method. Therefore, it can be concluded that the drying process by using Hohenheim type drier was better than that of sun drying method. Keywords: red ginger, drying, Hohenheim type dryer.

\section{PENDAHULUAN}

Jahe merah merupakan hasil pertanian yang banyak dibutuhkan oleh pasar. Diantara tanaman obat, jahe merah merupakan salah satu komoditas yang menempati posisi penting dalam perekonomian Indonesia, karena merupakan tanaman obat yang banyak diminta untuk keperluan jamu, industri obat, bumbu dan ekspor. Selain itu jahe merah juga sangat bermanfaat bagi kesehatan karena memiliki rasa yang paling pedas dan mengandung minyak atsiri yang sangat tinggi.

Permintaan jahe merah ini dari waktu ke waktu semakin tinggi. Tingginya tingkat permintaan jahe merah bisa dimaklumi, mengingat kebutuhan jahe merah ini tidak hanya dibutuhkan sebagai bahan bumbu masak di tingkat rumah tangga, tetapi juga sudah dibutuhkan oleh kalangan industri, seperti industri bumbu masak, industri obat-obatan, industri jamu tradisional, dan industri kosmetik, yang mana pangsa pasar dari industri-industri tersebut sudah cukup luas jangkauannya, tidak hanya pasar dalam negeri namun sudah mengarah pada 
penguasaan pasar di luar negeri. Menurut data yang terdapat dari Badan POM pada tahun 2015, diperkirakan permintaan terhadap jahe merah dapat lebih dari 2.000 ton per pekan.

Jahe merah dapat dipasarkan dalam bentuk jahe segar maupun jahe kering. Pada saat ini, dapat dilihat bahwa para petani masih banyak melakukan pengeringan dengan cara tradisional, yaitu dengan cara penjemuran langsung dengan memanfaatkan sinar matahari tanpa adanya alat pengering. Pengeringan dengan metode ini dinilai kurang efektif karena sangat rentan terhadap kontaminasi benda asing dan sangat tergantung oleh keadaan lingkungan. Dengan adanya alat pengering, diharapkan pengeringan akan menjadi lebih mudah dan efektif.

\section{Waktu dan Tempat}

\section{METODE PENELITIAN}

Penelitian ini dilaksanakan pada bulan Mei-Juli 2016, bertempat di Kebun Percobaan Fakultas Pertanian Universitas Syiah Kuala dan di Laboratorium Teknik Pasca Panen Program Studi Teknik Pertanian, Fakultas Pertanian, Universitas Syiah Kuala, BandaAceh.

\section{Alat dan Bahan}

Peralatan yang digunakan pada penelitian ini adalah seperangkat alat pengering tipe Hohenheim, terpal, alat perajang, timbangan analitik, termometer, kamera digital, oven, cawan petri, dan desikator. Bahan yang digunakan adalah rimpang jahe merah sebanyak $9 \mathrm{~kg}$.

\section{Prosedur Penelitian}

Prosedur penelitian yaitu disiapkan bahan baku utama berupa rimpang jahe merah. Rimpang disortasi kemudian dibersihkan dan ditimbang sebanyak $6 \mathrm{~kg}$, diiris tipis menggunakan slicer dengan ukuran ketebalan $\pm 3 \mathrm{~mm}$. Kemudian dipisahkan menjadi 2 bagian. Tiga kilogram rimpang jahe dikeringkan dengan cara dijemur di bawah sinar matahari dengan menggunakan alas terpal, dan $3 \mathrm{~kg}$ dikeringkan dengan menggunakan pengering tipe Hohenheim. Pengeringan dilakukan selama 7 jam, dimana jahe merah ditumpuk sebanyak 3 tumpukan untuk setiap metode pengeringan dengan berat masing-masing $1 \mathrm{~kg}$. Selama proses pengeringan parameter yang diamati adalah suhu dan kelembaban relatif (RH). Setelah dilakukan pengeringan maka dilakukan analisa terhadap susut bobot, kadar air, laju pengeringan, kontaminasi benda asing, dan perubahan warna jahe merah untuk menentukan mutu akhir dari pengeringan jahe merah.

\section{Rancangan Percobaan}

Rancangan penelitian yang digunakan adalah Rancangan Acak Kelompok (RAK) nonfaktorial dengan perlakuan metode pengeringan yang terdiri dari 2 taraf, yaitu pengeringan dengan cara penjemuran langsung (B1) dan pengeringan menggunakan alat pengering Hohenheim (B2), dimana bahan diletakkan dalam 3 tumpukan. 


\section{Parameter Penelitian}

\section{Suhu Pengeringan}

Pengukuran suhu dilakukan menggunakan termometer di lingkungan luar dan di dalam alat pengering setiap satu jam sekali selama 7 jam pengeringan.

\section{Kelembaban Relatif Pengeringan}

Pengukuran kelembaban relatif dilakukan selama satu jam sekali selama 7 jam pengeringan menggunakan termometer bola kering dan termometer bola basah.

\section{Susut Bobot}

Pengukuran susut bobot pada pengeringan rimpang jahe merah dihitung berdasarkan penurunan berat setelah dilakukan pengeringan. Sebanyak $1 \mathrm{~kg}$ jahe merah yang dikeringan dengan masing-masing metode pengeringan, diukur beratnya setiap satu jam. Perhitungan susut bobot pada rimpang jahe merah diukur berdasarkan Persamaan 1.

$$
\mathrm{SB}=\frac{\mathrm{m}_{1}-\mathrm{m}_{2}}{\mathrm{~m}_{1}} \times 100 \%
$$

keterangan:

SB : susut bobot (\%)

$\mathrm{m}_{1}$ : bobot awal $(\mathrm{g})$

$\mathrm{m}_{2}$ : bobot akhir $(\mathrm{g})$

\section{Kadar Air}

Perhitungan kadar air suatu bahan selama proses pengeringan berlangsung dihitung berdasarkan pada komponen massa seperti terdapat pada Persamaan 2.

$$
\text { Kadar Air (\% basis basah })=\frac{m_{w}}{m_{w}+m_{s}} \text { X } 100 \%
$$

Dimana :

$m_{w}: \quad$ Massa air $(\mathrm{g})$

$m_{s}: \quad$ Massa padatan $(\mathrm{g})$

\section{Kontaminasi Benda Asing}

Perhitungan terhadap kontaminasi benda asing dapat dilakukan dengan sortasi kering pada sampel yang telah dikeringkan dengan cara memisahkan sampel dari benda-benda asing seperti kerikil, tanah atau kotoran-kotoran lain. Kemudian ditimbang berat dari sampel untuk mengetahui persentase kontaminan. Perhitungan terhadap kontaminasi benda asing seperti terdapat pada Persamaan 3.

$$
\% \mathrm{k}=\frac{b 1}{b 2} \times 100 \%
$$

Keterangan:

$\% \mathrm{k}$ : persentase kontaminan $(\%)$

$\mathrm{b}_{1}$ : berat kontaminan $(\mathrm{g})$

$\mathrm{b}_{2}$ : berat sampel $(\mathrm{g})$

\section{Perubahan Warna}


Peninjauan warna pada jahe merah dilakukan setelah proses pengeringan terhadap rimpang jahe merah selesai. Jahe dikeringan dengan masing-masing metode, kemudian dilakukan pengujian menggunakan metode $\mathrm{L}^{*} \mathrm{a} * \mathrm{~b} *$ melalui software photoshop.Warna bahan makanan biasanya diukur dalam unit $\mathrm{L}^{*} \mathrm{a} * \mathrm{~b}$ yang merupakan standar internasional pengukuran warna. Sedangkan makna dari setiap dimensi yang dibentuk yaitu :

a. Dimensi L untuk mendeskripsikan kecerahan warna, 0 untuk hitam dan $\mathrm{L}=100$ untuk putih.

b. Dimensi a mendeskripsikan jenis warna hijau-merah, dimana angka a negatif mengindikasikan warna hijau dan sebaliknya jika a positif mengindikasikan warna merah.

c. Dimensi $b$ untuk jenis warna biru-kuning, dimana angka $b$ negatif mengindikasikan warna biru dan sebaliknya jika positif mengindikasikan warna kuning.

\section{ANALISIS DATA}

\section{Statistik Deskriptif}

Data suhu pengeringan dan kelembaban relatif (RH) ditampilkan secara deskriptif dalam bentuk table dan grafik dengan parameter nilai rata-rata, nilai maksimum, nilai minimum dan standar deviasi.

\section{ANOVA}

ANOVA (analysis of variance) dilakukan terhadap susut bobot, kadar air, dan kontaminasi benda asing. Berdasarkan rancangan penelitian ini, sumber keragaman terdiri dari perlakuan (antar kelompok) dengan derajat bebas 1, dan galat (dalam kelompok) dengan derajat bebas 4. Total derajat bebas keseluruhan adalah 5. Perhitungan ANOVA terhadap parameter penelitian dapat dirumuskan dalam Persamaan 4-8.

$$
\begin{aligned}
& \text { JKperlakuan } \quad=\frac{1}{n} \sum_{i=1}^{n} y_{i^{2}}-\frac{y^{2}}{N} \text {. } \\
& \text { JKtotal } \quad=\sum_{i=1}^{a} \sum_{j=1}^{n}\left(y_{i j}-\bar{y}\right)^{2} \\
& \text { JKgalat } \quad=\text { JKtotal }- \text { Jkperlakuan } \\
& \text { KTperlakuan }=\frac{\text { JKperlakuan }}{\text { DBperlakuan }} \\
& \text { KTgalat }=\frac{\text { J K galat }}{\text { DBgalat }}
\end{aligned}
$$

\section{Laju Pengeringan}

Laju pengeringan dapat dihitung dengan menggunakan Persamaan 9-10.

$$
\begin{aligned}
& K A_{b k}=\frac{m_{w}}{m_{s}} \times 100 \% \\
& \text { Lpi }=\frac{\mathrm{KAbk}_{(\mathrm{i}-1)}-\mathrm{KAbk}_{\mathrm{i}}}{\Delta \mathrm{t}}
\end{aligned}
$$


Keterangan :

Lpi : Laju pengeringan (\% bk/jam)

KAbk : Kadar air basis kering (\% bk)

$\Delta \mathrm{t} \quad$ : Selang waktu (jam)

\section{Pengeringan dengan Penjemuran}

\section{HASIL DAN PEMBAHASAN}

Pengeringan dengan cara penjemuran dilakukan dengan cara meletakkan bahan langsung di atas selembar terpal berwarna hitam (Gambar 1) dan dibagi menjadi 3 tumpukan. tiap tumpukan terdiri dari $1 \mathrm{~kg}$ jahe merah. Penggunaan terpal berwarna hitam dikarenakan warna hitam dapat menyerap panas dengan baik, sehingga diharapkan bahan dapat lebih cepat kering. Terpal tersebut diletakkan langsung diatas permukaan tanah berumput. Selain itu, metode ini digunakan mengadopsi metode yang umum diterapkan oleh masyarakat

Kelemahan dari pengeringan dengan metode penjemuran adalah penjemuran tidak dapat dilakukan pada saat cuaca tidak stabil seperti pada saat mendung dan hujan. Selain itu, jika terjadi angin, maka terpal dapat terlipat atau terangkat sehingga mengganggu proses pengeringan. Bahan yang dikeringkan dengan metode ini juga rentan terhadap kontaminasi benda asing dan gangguan hewan ternak. Namun saat penelitian berlangsung, bahan dapat terbebas dari kontaminasi dan gangguan hewan ternak karena lingkungan pengeringan yang mendukung untuk dilakukan pengeringan, sehingga kendala yang muncul hanya berupa perubahan cuaca.

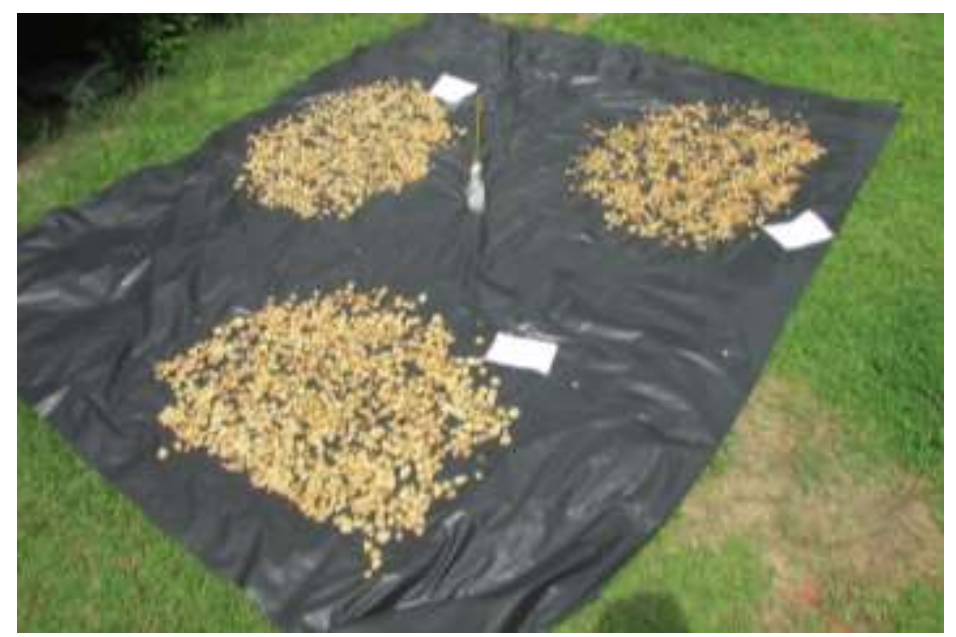

Gambar 1. Pengeringan Dengan Cara Penjemuran

\section{Alat Pengering Tipe Hohenheim}

Alert pioneering mbar Hohenheim merupakan alat pengering tipe terowongan berbasis energi matahari.Alat ini terdiri dari beberapa bagian yaitu kolektor, ruang pengering, sebuah panel surya, dan kipas. Alat ini memiliki ukuran $6 \mathrm{~m}$ x $2 \mathrm{~m}$, dengan ketinggian $1 \mathrm{~m}$ dari permukaan tanah. Luas absorber pada alat pengering tipe Hohenheim sama dengan luas alas pengeringnya, yaitu $3 \mathrm{~m} \times 2 \mathrm{~m}$. Radiasi panas diserap oleh absorber yang terdapat pada alat 
pengering, dan terperangkap dalam ruang pengering karena adanya lapisan plastik yang terdapat pada alat sebagai penutup. Dengan adanya absorber dan plastik penutup, maka panas dalam ruang pengering dapat terjaga dan suhu di dalam ruang pengering menjadi lebih tinggi dibandingkan suhu pada lingkungan.

Alat pengering tipe Hohenheim dilengkapi dengan 3 buah kipas. Kipas digerakkan energi listrik yang dihasilkan dari solar cell. Kipas berada di bagian inlet, sehingga dapat membawa udara dingin dari lingkungan luar alat masuk ke dalam alat pengering. Udara melewati absorber dan menerima panas yang diserap oleh absorber. Kemudian udara tersebut mengalir melewati bahan yang dikeringkan. Bagian-bagian dari alat pengering tipe Hohenheim dapat dilihat pada Gambar 2.

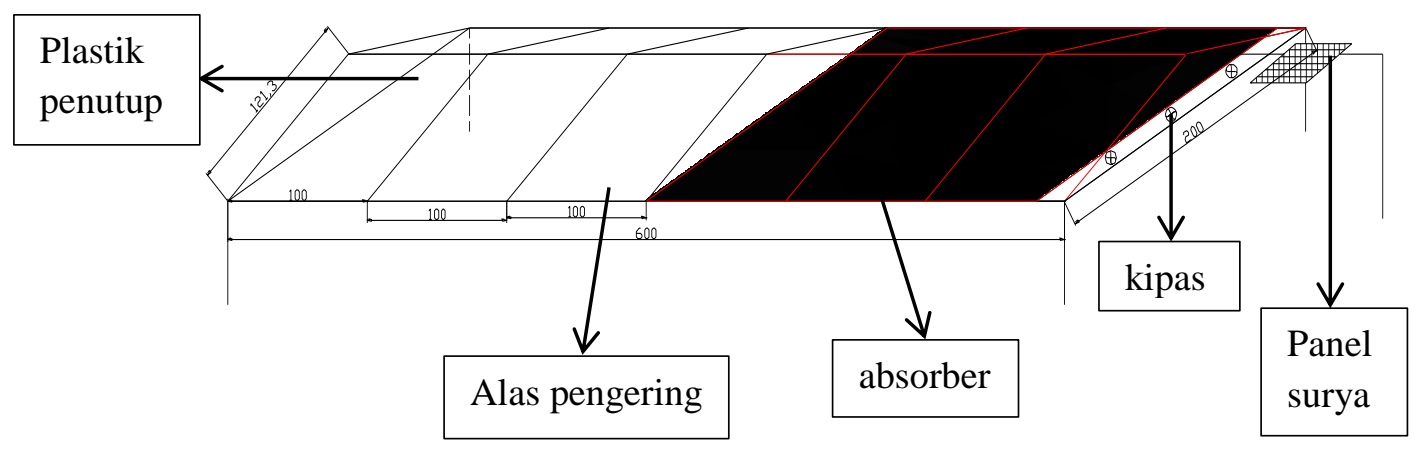

Gambar 2. Sketsa Alat Pengering Tipe Hohenheim (Syahputra, 2016)

\section{Suhu Pengeringan}

Selama berlangsungnya pengeringan, suhu tertinggi terjadi pada pukul 09.00 WIB. Suhu pada lingkungan luar saat itu adalah $34{ }^{\circ} \mathrm{C}$, sedangkan suhu pada alat pengering Hohenheim adalah $45^{\circ} \mathrm{C}$. Sementara itu, suhu terendah terdapat pada pukul 12.00 WIB. Hal ini terjadi disebabkan adanya hujan yang berlangsung pada saat itu. Suhu lingkungan yang tercatat pada saat itu adalah $22{ }^{\circ} \mathrm{C}$ dan suhu pada alat pengering tipe Hohenheim adalah $32{ }^{\circ} \mathrm{C}$. Rata- rata suhu pengeringan di lingkungan luar pada hari itu adalah $31^{\circ} \mathrm{C}$ dan pada ruang pengering adalah $40{ }^{\circ} \mathrm{C}$. Perbandingan suhu pengeringan jahe merah dengan kedua metode dapat dilihat pada Gambar 3.

Suhu merupakan parameter yang paling penting dalam proses pengeringan, karena semakin tinggi suhu maka semakin cepat pula proses pengeringan berlangsung. Menurut Winarno (1993), bahwa peningkatan suhu dapat mempercepat proses pengeringan dari produk pertanian, akan tetapi dengan menggunakan suhu yang terlalu tinggi juga dapat merusak tekstur dan tampilan bahan, sehingga bahan tersebut tidak bertahan lama. 


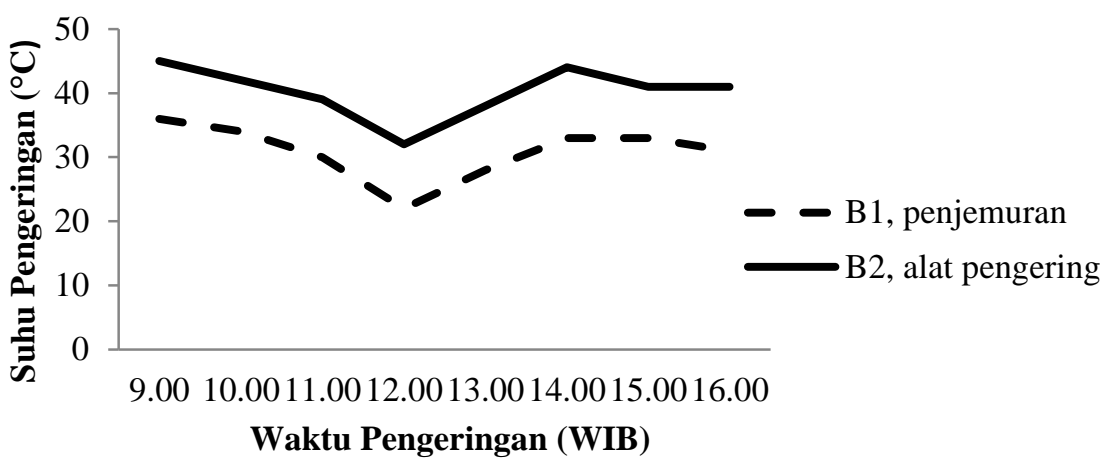

Gambar 3.Suhu Pengeringan Jahe Merah pada 2 Metode Pengeringan

\section{Kelembaban Relatif (RH)}

Dari hasil penelitian, didapatkan kelembaban relatif rata-rata di lingkungan selama pengeringan adalah $68,13 \%$, sementara rata-rata kelembaban relatif pada alat pengering tipe hohenheim adalah 51,5\%. Kelembaban relatif $(\mathrm{RH})$ pada kedua metode pengeringan dapat dilihat pada Gambar 4.

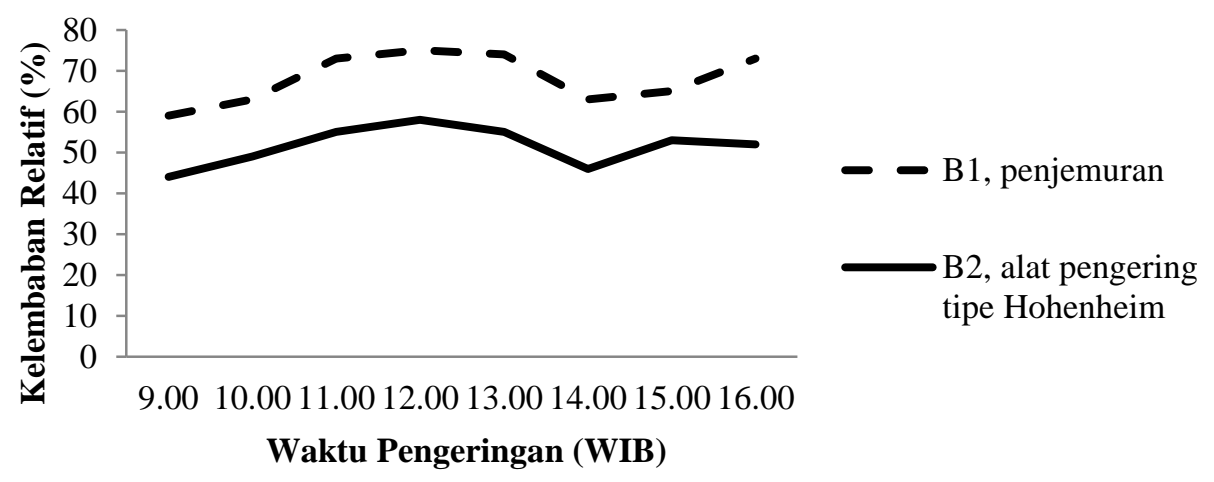

Gambar 4. Grafik Kelembaban Relatif (RH) pada Pengeringan Jahe Merah

Selama proses pengeringan berlangsung, dapat dilihat bahwa kelembaban relatif di lingkungan lebih tinggi daripada kelembaban relatif di dalam alat pengering tipe Hohenheim. Sesuai pernyataan Thahir (1988), bahwa semakin tinggi suhu maka kelembaban relatif (RH) akan semakin rendah dan sebaliknya jika suhu semakin rendah maka kelembaban relatif (RH) semakin tinggi. Hasil penelitian menunjukkan bahwa suhu pada alat pengering lebih tinggi dibandingkan suhu pada lingkungan.

\section{Susut Bobot}

Berdasarkan penelitian yang dilakukan, dapat diketahui bahwa total susut bobot pada proses penjemuran adalah 77,8\% dan pada alat pengering tipe Hohenheim adalah $82,5 \%$. Susut bobot tertinggi pada proses pengeringan terjadi pada pukul 11.00 WIB. Hal ini terjadi pada awal pengeringan. Tingginya kandungan air bebas pada bahan diawal pengeringan menyebabkan besarnya susut bobot pada awal proses pengeringan. Sementara susut bobot terendah, terdapat pada pukul 12.00 WIB. Pada saat itu terjadi hujan sehingga pengeringan tidak dapat dilakukan 
secara maksimal. Perbandingan susut bobot pada hasil pengeringan jahe merah dapat dilihat pada Gambar 5.

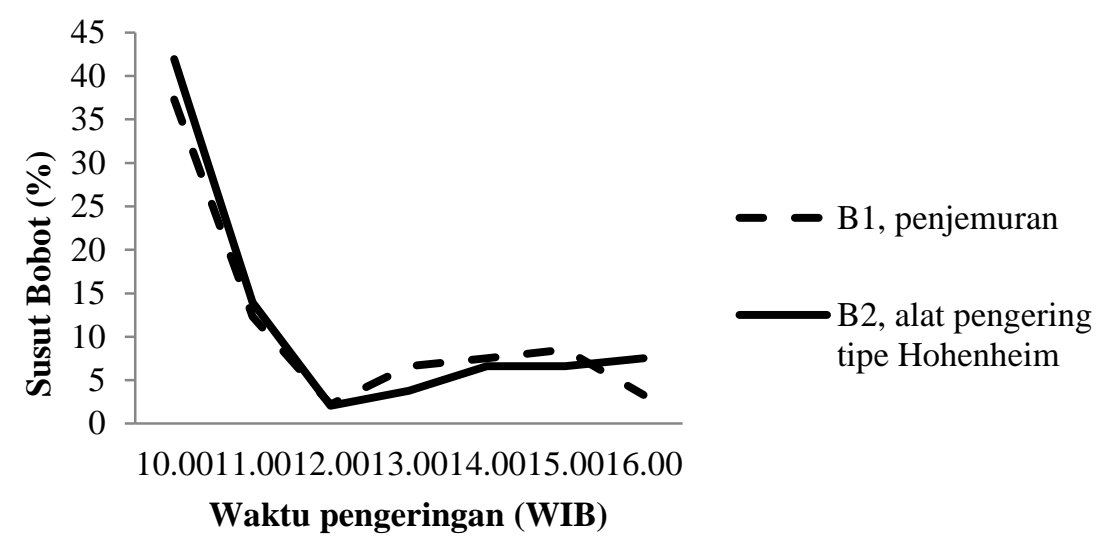

Gambar 5.Susut Bobot Jahe Merah Selama Proses Pengeringan

\section{Laju Pengeringan}

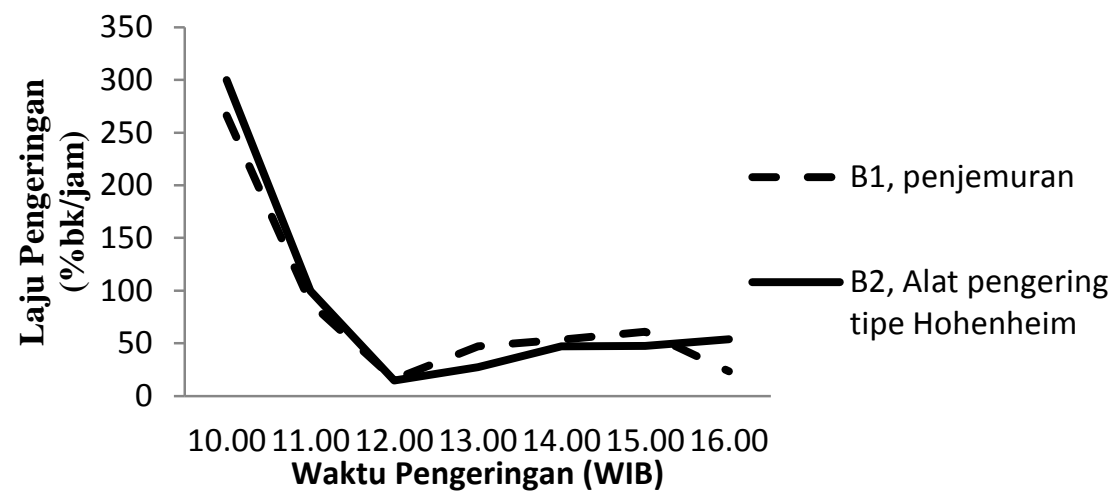

Gambar 6. Laju Pengeringan Jahe Merah

Dari gambar 6, dapat dilihat bahwa laju pengeringan tertinggi terdapat pada pengeringan jahe merah menggunakan alat pengering tipe Hohenheim. Hal ini diakibatkan suhu pada ruang pengering yang lebih tinggi daripada suhu di lingkungan. Laju pengeringan maksimum terjadi pada pukul 10.00 WIB, dengan laju pengeringan rata-rata pada penjemuran yaitu 266,43 $\%$ bk/jam dan rata-rata pada alat pengering tipe Hohenheim adalah 299,76 \%bk/jam. Sedangkan laju pengeringan minimum terjadi pada pukul 12.00 WIB.Hal ini disebabkan terjadinya hujan pada saat itu. Rata-rata laju pengeringan minimum pada penjemuran adalah $15,71 \% \mathrm{bk} / \mathrm{jam}$ dan pada alat pengering tipe Hohenheim adalah 14,52 \%bk/jam.

Dari penelitian yang dilakukan dapat dilihat terdapat perbedaan laju pengeringan dari kedua metode pengeringan yang dilakukan, namun pengeringan menggunakan alat pengering tipe Hohenheim ini lebih baik dibandingkan penjemuran langsung, dikarenakan suhu pada ruang alat pengering lebih tinggi sehingga mempercepat proses laju pengeringan. Hal ini sesuai dengan pernyataan Taib dkk. (1998) bahwa laju pengeringan bahan sangat ditentukan oleh 
suhu, semakin besar perbedaan suhu antara media pemanas dengan bahan yang dikeringkan, semakin cepat pindah panas kedalam bahan pangan, menyebabkan penguapan air dari bahan akan lebih banyak dan cepat.

\section{Kadar Air}

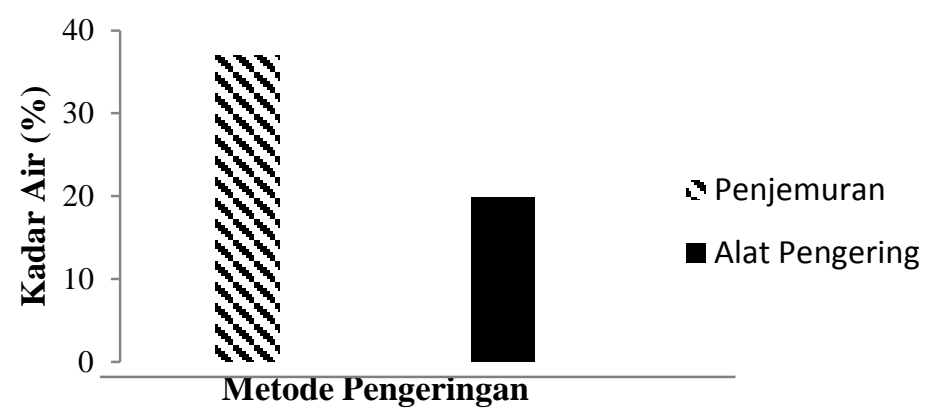

Gambar 7. Kadar Air Akhir Jahe Merah dengan Variasi Metode Pengeringan

Dari Gambar 7 dapat dilihat bahwa terdapat perbedaan yang signifikan antara kadar air pengeringan jahe merah dengan metode penjemuran langsung dan menggunakan alat pengering tipe Hohenheim. Pada penjemuran langsung, nilai rata-rata dari kadar air adalah 37,02\%, sedangkan kadar air jahe merah yang dikeringkan dengan menggunakan alat pengering tipe Hohenheim 19,84\%.

\section{Kontaminasi Benda Asing}

Keadaan lingkungan berpengaruh terhadap kontaminasi benda asing pada bahan yang dikeringkan Pada penelitian ini, kontaminasi yang terdapat pada pengeringan di luar alat adalah $0,06 \%$. Sedangkan pada pengeringan menggunakan alat pengering hohenheim adalah $0 \%$, atau tidak terdapat kontaminasi sama sekali. Hal ini disebabkan lingkungan penelitian yang bersih dan tanahnya ditutupi oleh rumput.

Namun pada kenyataannya, pengeringan dengan metode penjemuran sangat rentan terhadap kontaminasi benda asing, terlebih lagi jika penjemuran dilakukan di pinggir jalan atau tempat terbuka lainnya. Selain itu, gangguan dari hewan ternak dan kencangnya angin pada saat penjemuran juga mempengaruhi persentase kontaminan.

\section{Perubahan Warna}

Menurut Leon dkk. (2006) dalam Ikhwanto (2011), dalam rangka melakukan analisis citra digital di makanan, perlu untuk mengetahui ukuran warna setiap pixel pada permukaan suatu makanan.

Dari penellitian, diperoleh rata-rata nilai L tertinggi adalah 100, yaitu pada pengeringan menggunakan alat pengering tipe Hohenheim. Sedangkan rata-rata nilai L untuk metode penjemuran adalah 97,14 . Nilai L berfungsi untuk mengindikasi kecerahan dari suatu sampel.Oleh karena itu, semakin tinggi nilai L dari suatu sampel maka semakin cerah pula warna sampel tersebut. 
Rata-rata nilai a tertinggi yaitu -14,10, didapat dari penjemuran langsung. Sedangkan untuk rata-rata nilai a terendah yaitu $-15,82$ didapat dari pengeringan menggunakan alat pengering tipe Hohenheim. Rata-rata nilai b tertinggi yaitu 9,30, diperoleh dari pengeringan jahe menggunakan metode penjemuran langsung. Sementara rata-rata nilai a terendah yaitu 0,10 , diperoleh dari pengeringan menggunakan alat pengering tipe Hohenheim.

Berdasarkan pengujian warna pada jahe segar, diketahui nilai L adalah 100, nilai a adalah 15,48 dan nilai b adalah 2,24. Dari pengujian yang dilakukan, dapat dilihat bahwa hasil pengeringan menggunakan alat pengering tipe Hohenheim menghasilkan warna yang mendekati warna jahe segar. Oleh karena itu dapat dikatakan bahwa pengeringan menggunakan alat pengering tipe Hohenheim lebih baik dibandingkan penjemuran.

\section{SIMPULAN DAN SARAN}

Rata-rata suhu pada alat pengering tipe Hohenheim lebih tinggi dibandingkan suhu pada lingkungan, sehingga menyebabkan kelembaban relatif pada alat pengering lebih rendah dibandingkan pada lingkungan. Susut bobot dan laju pengeringan pada pengeringan jahe merah menggunakan alat pengering tipe Hohenheim lebih tinggi dibandingkan pada metode penjemuran. Kadar air jahe merah yang dikeringkan dengan menggunakan alat pengering tipe Hohenheim signifikan lebih rendah dibandingkan kadar air pada jahe merah yang dikeringkan dengan metode penjemuran. Metode pengeringan tidak berpengaruh terhadap kontaminasi benda asing.Pengeringan menggunakan alat pengering tipe Hohenheim menghasilkan warna jahe merah yang lebih cerah dibandingkan pada penjemuran. Adapun saran yang dapat diberikan yaitu perlu dilakukannya penelitian lebih lanjut dengan pengeringan hingga kadar air $10 \%$ sehingga dapat menghasilkan simplisia jahe merah.

\section{DAFTAR PUSTAKA}

Syahputra, I. R. 2016. Pengaruh pengeringan menggunakan alatpengering tipe terowongan (Hohenheim) terhadap mutu cabai merah kering (Capsicum annuиm L).Skripsi. Program Studi Teknik Pertanian Fakultas Pertanian, Universitas Syiah Kuala, Banda Aceh.

Taib, G., G, Said dan S. Wiraatmadja. 1988. Operasi Pengeringan Pada Pengolahan Hasil Pertanian, PT Mediatama Sarana Perkasa, Jakarta.

Thahir, R. 1988. Teknologi Pasca Panen Jagung. Pusat Penelitian dan Pengembangan Tanaman Pangan, Bogor.

Winarno, F G. 1993. Pangan, Gizi, Teknologi dan Konsumen. Gramedia Pustaka Utama, Jakarta.

Ikhwanto, K. 2015. Pengaruh variasi ketebalan irisan ubi jalar ungu (Ipomoea balatas L) dan konsentrasi natrium bikarbonat $(\mathrm{NaHCO} 3)$ terhadap perubahan sifat fisika pasca penggorengan. Skripsi. Program Studi Teknik Pertanian Fakultas Pertanian, Universitas Syiah Kuala, Banda Aceh. 